\title{
PENGEMBANGAN MOBILE LEARNING PENGUKURAN LISTRIK UNTUK SISWA PROGRAM KEAHLIAN TITL DI SMK
}

\author{
Asni Tafrikhatin \\ Program Studi Teknik Elektro, Politeknik Dharma Patria Kebumen, Kebumen, Indonesia \\ Email: asni20081992@gmail.com
}

\begin{abstract}
Abstrak
Penelitian ini bertujuan untuk mengembangkan mobile learning materi pengukuran listrik. Model pengembangan yang digunakan merupakan model penelitian Waterfall. Model pengembangan Waterfall terdiri dari communication, planning, modelling, dan construction. Subjek penelitian ini adalah guru dan siswa kelas X program keahlian TITL SMK Negeri 3 Yogyakarta, SMK Negeri 1 Pundong, SMK Taman Siswa Yogyakarta, dan SMK Muhammadiyah 3 Yogyakarta. Teknik analisis data yang digunakan deskriptif. Hasil penilaian kelayakan mobile learning menurut validator sebesar 80,30 dan menurut siswa sebesar 85,59 dari skala 100 sehingga dikategorikan "Sangat Layak". Hasil penilaian keberfungsian mobile learning menurut validator sebesar 83,25 dan menurut siswa sebesar 86,66 dari skala 100 sehingga dikategorikan "Sangat Layak".
\end{abstract}

Kata kunci: Media pembelajaran, Mobile learning, Pengukuran listrik

\begin{abstract}
This study aims to developing mobile learning material electrical measurement. The research is a research and development that uses Waterfal research modell. Waterfall model development which consists of four stages: communication, planning, modelling, and construction. The subjects of this study were teachers and students of X class of Electrical Installation Study Program from SMK Negeri 3 Yogyakarta, SMK Negeri 1 Pundong, SMK Taman Siswa Yogyakarta, and SMK Muhammadiyah 3 Yogyakarta. The data were analyzed using descriptive. The result of mobile learning feasibility assessment according to validator was 80.30 and students equal to 85.59 from scale 100 so categorized as "Very Eligible". The result of mobile activity functionality evaluation according to validator was 83.25 and students equal to 86.66 from scale 100 so categorized "Very Eligible".
\end{abstract}

Keywords: Learning media, Mobile learning, Electrical measurement

\section{PENDAHULUAN}

Mata pelajaran kelompok C (peminatan) terdapat pada struktur kurikulum tahun 2013 di Sekolah Menengah Kejuruan (SMK). Program keahlian Teknik Instalasi Tenaga Listrik (TITL) terdiri dari beberapa mata pelajaran, salah satu kelompok mata pelajaran peminatan adalah mata pelajaran dasar dan pengukuran listrik. Mata pelajaran dasar dan pengukuran listrik diberikan di kelas X karena mata pelajaran tersebut merupakan mata pelajaran dasar untuk program keahlian TITL. Salah satu materi pada mata pelajaran dasar dan pengukuran listrik adalah pengukuran listrik. Siswa yang mengikuti program keahlian TITL diwajibkan untuk memahami mata pelajaran kelompok C.

Guru mengajarkan materi dengan metode pembelajaran yang kurang menarik dan kurang efektif. Banyak siswa yang masih merasa bosan ketika pembelajaran di kelas dengan menggunakan metode pembelajaran berpusat pada guru. Beberapa guru masih mengandalkan media pembelajaran berupa buku mata pelajaran (textbook). Berdasarkan hasil wawancara dengan beberapa siswa di SMK (Asni, 2017), kebosanan siswa diwujudkan dengan berbicara pada temannya, membuka gawai baik untuk bermain game, chatting dengan teman maupun menggunakan media sosial pada saat proses belajar mengajar berlangsung. Larangan mengaktifkan gawai saat proses belajar mengajar sudah ada, namun masih banyak siswa yang tetap mengaktifkan gawai. Hal ini disebabkan siswa dapat memanfaatkan waktu lengah guru, namun terkadang kekurangtegasan guru dalam menegakkan peraturan sekolah juga menjadi penyebab. Oleh karena itu, guru harus mengajar dengan metode pembelajaran yang menarik.

Peran usia berpengaruh terhadap intensitas seseorang memegang gawai. Pernyataan tersebut selaras dengan hasil survey Kominfo (2016) menunjukkan bahwa tingkat kepemilikan gawai pada 
umur 9-15 tahun sebesar 67,8\%; umur 16-25 tahun sebesar 78,9\%; umur 26-35 tahun sebesar 73,9\%; umur 36-45 tahun sebesar 72,2\%; 46-55 tahun sebesar 71\%; dan umur 56-65 tahun sebesar $67,6 \%$. Hal ini berarti umur siswa SMK memiliki tingkat kepemilikan gawai yang paling tinggi. Berdasarkan wawancara dengan berbagai siswa di SMK (Asni, 2017), siswa mengatakan bahwa siswa merasa tidak dapat jauh dari gawai. Hasil dari wawancara beberapa siswa di SMK mengatakan bahwa kurang lebih 4 jam dalam sehari, siswa menggunakan gawai. Hal ini berarti siswa SMK mulai ketergantungan gawai sehingga perlu diperhatikan dalam proses pembelajaran.

Siswa sering mengakses internet daripada membaca buku. Budaya membaca buku di kalangan siswa mulai ditinggalkan. Sebagian besar siswa mengerjakan tugas hanya dengan mencari materi di google dan mengambil sumber dari blog yang ada. Ketepatan ilmu yang disampaikan di blog belum tentu benar sehingga harus membuka beberapa blog untuk memastikan kebenarannya. Penelitian yang dilakukan oleh pasar comScore menunjukkan terdapat 63,6 juta pengguna internet di Indonesia, jumlah tersebut terdiri dari 21,2 juta pengguna menggunakan desktop dan 51,4 juta pengguna menggunakan gawai dan tablet (Tribun, 2017). Pengguna internet meningkat karena semakin banyak harga paket data yang ditawarkan oleh perusahaan penyedia jasa internet dan banyak tempat umum yang memberikan akses free wifi. Hal ini menyebabkan siswa cenderung sering mengakses materi dari internet.

Sebagian besar siswa SMK memiliki gawai dengan sistem operasi android. Playstore belum banyak menyediakan aplikasi pembelajaran untuk siswa SMK terutama untuk kelompok mata pelajaran peminatan. Salah satu mata pelajaran peminatan untuk program keahlian TITL adalah pengukuran listrik. Materi pengukuran listrik secara umum mencakup bahan-bahan kelistrikan pada arus searah, analisis rangkaian arus searah, dan pengukuran dengan alat ukur analog arus searah. Materi-materi tersebut membutuhkan gambar, video, ataupun simulasi yang jelas untuk menjelaskan ke siswa. Salah satu cara pengemasan materi tersebut menggunakan mobile learning. Berdasarkan survey Quipper (Husada, 2015) dari 1000 siswa dan 200 guru, terdapat 55\% yang aktif dalam pembelajaran menggunakan perangkat seluler. Hal ini berarti siswa dan guru mulai memandang gawai menjadi salah satu media pembelajaran yang praktis dan efisien.

Penggunaan media belajar yang tepat akan dapat mendukung pembelajaran yang sesuai dengan tujuan pembelajaran. Materi yang diajarkan di sekolah kejuruan lebih bersifat aplikatif, sehingga siswa dituntut untuk dapat memahami materi yang diajarkan. Guru mata pelajaran produktif juga harus menjelaskan materi dengan cara memvisualisasikan agar siswa tidak hanya mengetahui dengan materi yang diajarkan namun juga memahaminya. Kesalahan dalam memahami materi yang diajarkan dapat berakibat fatal karena mata pelajaran keahlian sangat bermanfaat di dunia kerja. Berdasarkan uraian di atas, maka diperlukan media pembelajaran yang memberikan kebermaknaan bagi siswa, dapat digunakan tanpa dibatasi ruang dan waktu serta dapat mengevaluasi diri sendiri

Proses kegiatan pembelajaran dikatakan berhasil jika tujuan pembelajaran telah tercapai. Keberhasilan proses kegiatan belajar mengajar dipengaruhi oleh beberapa komponen. Komponen pembelajaran diantaranya adalah pendidik, siswa, lingkungan, metode/teknik serta media pembelajaran. Media pembelajaran (Hanafiah dan Suhana, 2012: 59) adalah sesuatu hal yang dipersiapkan guru untuk menyalurkan ilmu ke siswa sehingga siswa memiliki keinginan yang tinggi untuk memahami dengan cepat, tepat dan tidak terjadinya verbalisme. Heinich (2002: 9) berpendapat bahwa media adalah alat untuk menyampaikan informasi. Akhtar dan Ali (2008: 35) mengemukakan bahwa media adalah sarana untuk menyampaikan pesan dalam proses belajarmengajar, pengiriman konten dari pengajar kepada siswa, untuk mencapai instruksi yang efektif. Dari beberapa pendapat dapat disimpulkan bahwa media pembelajaran adalah sesuatu yang digunakan pengajar untuk meneruskan ilmu ke siswa dalam proses belajar mengajar agar terjadi proses pembelajaran yang efektif.

Belajar menggunakan media pembelajaran yang berbasis teknologi sebaiknya memiliki konektivitas dan interaktivitas antar siswa, siswa dengan guru, dan siswa dengan lembaga pendidikan agar dapat dikontrol satu dengan yang lain. Materi yang ada pada media pembelajaran teknologi sebaiknya juga bersifat sepanjang masa dan menggunakan skala tertentu agar dapat digunakan tidak hanya untuk kalangan sendiri namun dapat digunakan oleh siapapun, sehingga diusahakan media tersebut bersifat open source. Media pembelajaran berbasis teknologi merupakan sarana alternatif dalam melakukan proses pembelajaran dikarenakan beberapa hal diantaranya yaitu mudah dibuat dalam proses pembelajaran, lebih menarik untuk pembelajaran, dan dapat diperbaiki setiap saat (Haryoko, 2009: 2). Pemanfaatan media pembelajaran berbasis 
teknologi/multimedia memiliki tiga tipe yaitu pembelajaran di kelas, materi pembelajaran mandiri, dan media tunggal di dalam pembelajaran (Waryanto, 2008: 8).

Mobile learning adalah pembelajaran dengan konsep baru dan berisi konten yang mudah digunakan, serta tidak melibatkan lokasi dimana pembelajar itu melakukannya (Hulme dan Traxler, 2005: 1). Senada dengan Hulme dan Traxler, Ally (2009: 1) mengemukakan bahwa mobile learning merupakan pembelajaran dengan teknologi mobile wireless sehingga memungkinkan siswa dapat mengakses informasi dan materi pembelajaran dimana saja dan kapan saja. Semua orang juga dapat mengakses materi pembelajaran dan informasi untuk menambah wawasan. Siswa juga dapat mengevaluasi secara sendiri. Darmawan (2012: 15) menjelaskan mobile learning adalah salah satu media pembelajaran yang berbentuk layanan pembelajaran yang dapat dilaksanakan dimana saja dan kapan saja. Mobile learning didasari alasan bahwa pembelajaran dapat dilakukan dimana saja dan kapan saja. Mobile learning dalam konteks saat ini adalah salah satu media pembelajaran yang menggunakan teknologi jaringan mobile untuk mengakses hal yang ingin diketahui atau menyimpan hal baru yang dapat diakses dimana dan kapan saja. Siswa dihubungkan langsung dengan komputasi menggunakan perangkat mobile untuk melakukan proses belajar atau menambah ilmu.

Pengembangan media pembelajaran harus memperhatikan kurikulum, silabus, dan RPP. Hal ini dilakukan untuk menyesuaikan media pembelajaran yang akan dibuat dengan desaim pembelajaran di kelas. Perancangan media pembelajaran melalui enam tahap, yaitu (a) menganalisis kebutuhan dan karakteristik siswa, (b) merumuskan tujuan pembelajaran, (c) merumuskan butir-butir materi, (d) menyusun instrumen evaluasi, (e) menulis naskah pada media, (f) melakukan evaluasi, dan (g) uji coba lapangan (Sadiman, 2014: 100).

Rodger (2005: 334) menyebutkan bahwa sebuah media yang baik harus memenuhi empat syarat utama yaitu: (1) attention (perhatian): perhatian siswa dapat selalu terjaga, sehingga diperlukan strategi yang tepat untuk menarik perhatian siswa, (2) relevance (relevansi): media pembelajaran harus dirancang untuk menunjukkan bahwa informasi yang mereka dapat sangat dibutuhkan ketika siswa bekerja atau dalam kehidupan sehari-hari, (3) convidence (keyakinan): media pembelajaran diharapkan dapat menyakinkan siswa bahwa siswa mampu mempelajari materi tersebut sehingga motivasi akan terbangun, dan (4) satisfaction (kepuasan): siswa harus puas dengan pengalaman belajar yang siswa peroleh. Media pembelajaran yang baik harus dapat menarik perhatian siswa, media pembelajaran tersebut juga memiliki kesesuaian dengan materi yang ada. Media pembelajaran juga diharapkan dapat meyakinkan siswa sehingga siswa merasa puas dengan materi yang diberikan.

Mobile learning menjadi media pembelajaran yang layak jika memenuhi prinsip sebagai berikut: (a) penggunaan media sesuai dengan kebutuhan belajar, (b) media tidak hanya untuk hiburan tetapi juga untuk belajar, (c) media memiliki akses yang mudah dan fleksibel, (d) media merupakan ekspresi diri yang kreatif, (e) media memicu berpikir kritis, (f) media mencerminkan target dan tujuan dari hasil yang dihasilkan, (g) media harus dihubungkan dengan kehidupan nyata, dan (h) media yang dihasilkan harus berkualitas dan memiliki relevansi dengan materi pembelajaran (Zabaleta, 2012: 7). Penilaian pengembangan mobile learning didasarkan oleh beberapa komponen, yaitu, isi pembelajaran, keterampilan teknologi, keterampilan desain, dan kesesuaian media (Ivers dan Barron, 2002: 138). Senada dengan Kementrian Pendidikan Nasional (2010) tentang pengembangan bahan ajar berbasis TIK yaitu substansi materi, desain pembelajaran, tampilan, dan pemanfaatan software.

Pengembangan aplikasi yang berkualitas tidak lepas dari standar yang digunakan sebagai indikator keberfungsian sebuah software. Beberapa perusahaan pengembang perangkat lunak diharuskan memenuhi standar kelayakan aplikasi, tidak lepas dari itu International Standards Organization atau ISO, mengeluarkan standar kelayakan software yang dikemas dalam ISO 9126. Djoub dan Bari (2016: 370) juga menyatakan bahwa penilaian media pembelajaran berbasis teknologi lebih tepat menggunakan ISO 9126. ISO 9126 mengklasifikasikan pengujian kualitas software berdasarkan tiga kategori yakni quality model framework, quality model for external and internal quality, dan quality model for quality in use. Secara keseluruhan kategori yang harus dimiliki oleh pengembang software adalah kualitas internal dan eksternal yang mencakup enam karakteristik yaitu functionality, reliability, usability, efficiency, maintainability, danportability.

Kearsley et al (1995: 40) menyatakan efektivitas dapat diartikan sebagai tindakan keberhasilan siswa untuk mencapai tujuan tertentu yang dapat membawa hasil belajar secara maksimal. Keefektifan proses pembelajaran berkaitan teknik dan strategi yang digunakan dalam mencapai tujuan secara optimal, tepat dan cepat. Rath et al. (2002: 363) efektivitas adalah tindakan atau 
usaha yang membawa hasil. Mengacu dari beberapa pengertian efektivitas yang telah dikemukakan oleh para ahli maka peneliti dapat menarik kesimpulan bahwa efektivitas adalah tingkat keberhasilan yang dicapai dari penerapan suatu model pembelajaran, dalam hal ini diukur dari hasil belajar siswa, apabila hasil belajar siswa meningkat maka media pembelajaran tersebut dapat dikatakan efektif, sebaliknya apabila hasil belajar siswa menurun atau tetap (tidak ada peningkatan) maka media pembelajaran tersebut dinilai tidak efektif. Jadi tingkat keefektifan media pembelajaran mobile learning diukur dari output.

\section{MATERI DAN METODE}

Model pengembangan Waterfall merupakan model pengembangan software oleh Pressman (2012 : 29) yang terdiri dari 5 tahapan yaitu communication, planning, modelling, construction, dan deployment. Tahapan deployment tidak digunakan karena sampel yang diambil dalam penelitian ini kurang luas hanya empat kelas. Tahap-tahap model pengembangan Waterfall disajikan pada Gambar 1.

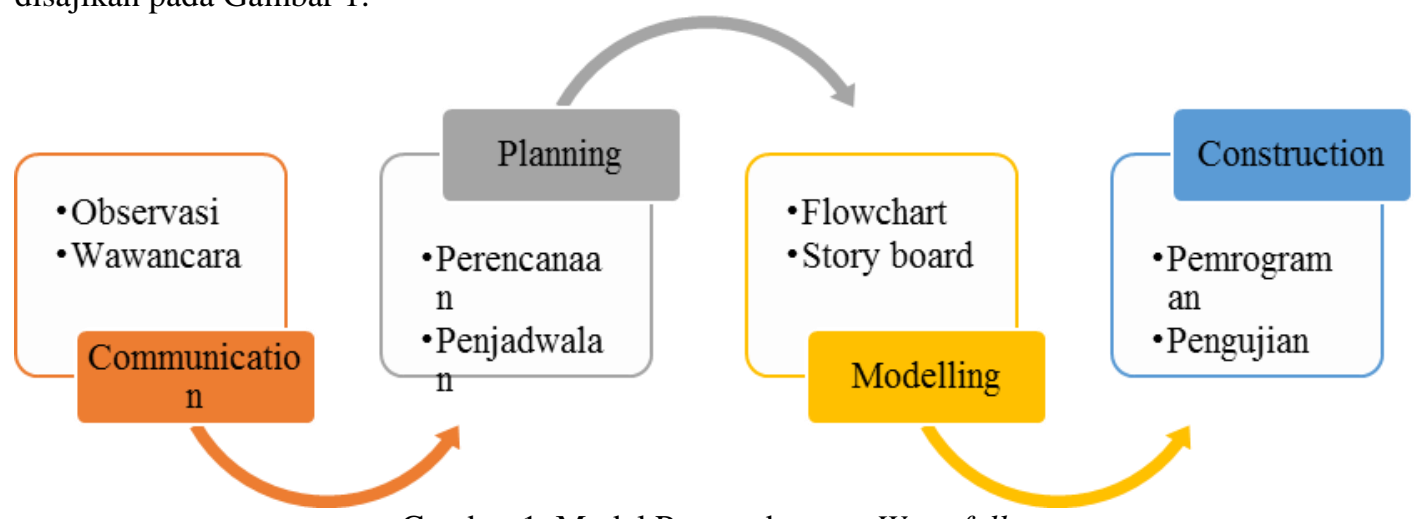

Gambar 1. Model Pengembangan Waterfall

Subjek penelitian ini adalah siswa kelas X program keahlian TITL SMK Negeri 3 Yogyakarta, SMK Negeri 1 Pundong, SMK Taman Siswa Yogyakarta, dan SMK Muhammadiyah 3 Yogyakarta. Validasi produk dilakukan oleh dua orang dosen dan tujuh orang guru SMK menggunakan angket. Uji coba produk dilakukan oleh 100 orang siswa. Instrumen pengumpulan data menggunakan angket untuk respon siswa.

\section{HASIL DAN PEMBAHASAN}

\subsection{Hasil}

Hasil produk media pembelajaran yang dibuat adalah aplikasi android dengan nama DPLdroid. DPLdroid tersebut disajikan pada Gambar 2.

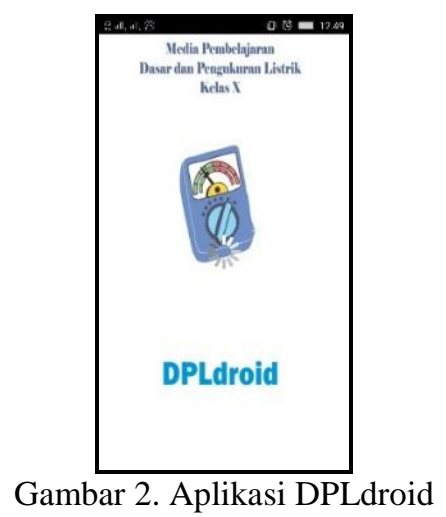

Media pembelajaran yang dibuat adalah berupa aplikasi android dengan nama DPLdroid. Kapasitas dari DPLdroid adalah 17 MB. Setelah aplikasi tersebut jadi, selanjutnya aplikasi tersebut dicoba dari keberfungsian tombol-tombol navigasi dan video dapat berjalan dengan baik atau tidaknya menggunakan angket black box testing. Uji coba ini dilakukan oleh tiga orang dengan menggunakan berbagai merk smartphone dengan ukuran layar yang berbeda, versi android yang 
berbeda, kapasitas RAM yang berbeda, dan kecepatan internet yang berbeda pula. Berdasarkan hasil uji coba tersebut dapat disimpulkan bahwa aplikasi DPLdroid dapat berjalan sesuai fungsinya.

Kelayakan mobile learning yang dikembangkan dinilai dari aspek substansi materi dan desain pembelajaran. Jumlah pernyataan yang diajukan untuk aspek substansi materi terdiri dari tiga indikator yaitu kedalaman, kekinian, dan keterbacaan materi, masing-masing indikator dikembangkan menjadi beberapa butir pernyataan dan secara keseluruhan sebanyak 13 butir pernyataan. Jumlah pernyataan yang diajukan untuk aspek desain pembelajaran terdiri dari enam indikator, yaitu judul, kompetensi dasar, materi, contoh soal, latihan, dan referensi, masing-masing indikator dikembangkan menjadi beberapa butir pernyataan dan secara keseluruhan sebanyak 16 pernyataan. Pernyataan dalam angket menggunakan rating skala 1-4. Skor yang diperoleh dari angket kemudian dikonversikan menjadi nilai dengan skala 1-100 untuk menentukan kategori penilaian. Hasil penilaiai kelayakan mobile learning disajikan pada Tabel 1.

Tabel 1. Hasil Penilaian Kelayakan Mobile learning Menurut Ahli

\begin{tabular}{ccccccc}
\hline & \multicolumn{3}{c}{ Dimensi } & \multicolumn{2}{c}{ Total Rata-Rata } \\
\cline { 2 - 6 } Ahli & \multicolumn{2}{c}{$\begin{array}{c}\text { Substansi } \\
\text { Materi }\end{array}$} & \multicolumn{2}{c}{ Desain } & & \\
& Pembelajaran & & Kat \\
\cline { 2 - 6 } $\mathbf{1}$ & 76.92 & SL & 78.13 & SL & 77.52 & SL \\
\hline $\mathbf{2}$ & 75.00 & L & 75.00 & L & 75.00 & L \\
\hline $\mathbf{3}$ & 84.62 & SL & 84.38 & SL & 84.50 & SL \\
\hline $\mathbf{4}$ & 76.92 & SL & 95.31 & SL & 86.12 & SL \\
\hline $\mathbf{5}$ & 75.00 & L & 75.00 & L & 75.00 & L \\
\hline $\mathbf{6}$ & 76.92 & SL & 95.31 & SL & 86.12 & SL \\
\hline $\mathbf{7}$ & 76.92 & SL & 81.25 & SL & 79.09 & SL \\
\hline $\mathbf{8}$ & 76.92 & SL & 81.25 & SL & 79.09 & SL \\
\hline Rata & 77.40 & SL & 83.20 & SL & 80.30 & SL \\
\hline
\end{tabular}

Keterangan:

$$
\begin{array}{ll}
\text { SL } & \text { : Sangat Layak } \\
\text { L } & \text { : Layak }
\end{array}
$$

Aspek kelayakan terdiri dari substansi materi dan desain pembelajaran. Berdasarkan uji validasi tersebut, materi pada mobile learning sudah cukup sesuai dengan kompetensi pengukuran listrik, bahasa yang digunakan mudah dipahami, dan contoh-contoh soal yang dapat membantu siswa untuk latihan mengerjakan soal. Hasil uji validasi tersebut juga terdapat beberapa indikator yang memiliki penilaian rendah. Penilaian terendah pada substansi materi terletak pada indikator kekinian dengan nilai sebesar 75. Indikator keterbacaan terdapat penilaian terendah pada penjelasan materi tentang daya dan kalimat yang masih ada yang kurang lugas. Penilaian terendah pada desain pembelajaran terletak pada kesesuaian contoh soal dengan materi analisis rangkaian DC yaitu sebesar 75. Berdasarkan hasil uji validasi, materi dalam mobile learning ini masih diperlukan perbaikan diantaranya: perbaikan kalimat yang masih kurang lugas, penjelasan materi daya yang masih kurang mendalam, dan contoh soal rangkaian DC yang kurang bervariasi.

Keberfungsian mobile learning yang dikembangkan dinilai dari aspek functionality, potability, usability, dan layout. Jumlah pernyataan yang diajukan untuk aspek functionality terdiri dari dua indikator yaitu fungsi dan performa, masing-masing indikator dikembangkan menjadi beberapa butir pernyataan dan secara keseluruhan sebanyak 3 butir pernyataan. Jumlah pernyataan yang diajukan untuk aspek portability terdiri dari dua indikator yaitu pemasangan dan adaptasi, masing-masing indikator dikembangkan menjadi beberapa butir pernyataan dan secara keseluruhan sebanyak 4 pernyataan. Jumlah pernyataan yang diajukan untuk aspek usability terdiri dari tiga indikator, yaitu keefektifan, kegunaan, dan membangkitkan antusias siswa, masingmasing indikator dikembangkan menjadi beberapa butir pernyataan dan secara keseluruhan sebanyak 4 pernyataan. Jumlah pernyataan yang diajukan untuk aspek layout terdiri dari enam indikator, yaitu keterbacaan teks, tata letak teks, pemilihan warna, pemilihan gambar, pemilihan video, dan tata letak tombol, masing-masing indikator dikembangkan menjadi beberapa butir 
pernyataan dan secara keseluruhan sebanyak 9 pernyataan. Pernyataan dalam angket menggunakan rating skala 1-4. Skor yang diperoleh dari angket kemudian dikonversikan menjadi nilai dengan skala 1-100 untuk menentukan kategori penilaian. Hasil penilaian keberfungsian mobile learning menurut Ahli disajikan pada Tabel 2.

Tabel 2. Hasil Penilaian Keberfungsian Mobile learning Menurut Ahli

\begin{tabular}{|c|c|c|c|c|c|c|c|c|c|c|}
\hline \multirow[t]{3}{*}{ Ahli } & \multicolumn{8}{|c|}{ Dimensi } & \multirow{2}{*}{\multicolumn{2}{|c|}{$\begin{array}{c}\text { Total } \\
\text { Rata-Rata }\end{array}$}} \\
\hline & \multicolumn{2}{|c|}{ Functionality } & \multicolumn{2}{|c|}{ Portability } & \multicolumn{2}{|c|}{ Usability } & \multicolumn{2}{|c|}{ Layout } & & \\
\hline & Nilai & Kat & Nilai & Kat & Nilai & Kat & Nilai & Kat & Nilai & Kat \\
\hline 1 & 91.67 & SL & 83.33 & SL & 81.25 & SL & 77.78 & SL & 83.51 & SL \\
\hline 2 & 75.00 & $\mathrm{~L}$ & 83.33 & SL & 81.25 & SL & 69.44 & $\mathrm{~L}$ & 77.26 & SL \\
\hline 3 & 83.33 & SL & 91.67 & SL & 68.75 & $\mathrm{~L}$ & 88.89 & SL & 83.16 & SL \\
\hline 4 & 91.67 & SL & 91.67 & SL & 93.75 & SL & 83.33 & SL & 90.10 & SL \\
\hline 5 & 75.00 & $\mathrm{~L}$ & 83.33 & SL & 81.25 & SL & 75.00 & $\mathrm{~L}$ & 78.65 & SL \\
\hline 6 & 91.67 & SL & 91.67 & SL & 93.75 & SL & 83.33 & SL & 90.10 & SL \\
\hline 7 & 75.00 & $\mathrm{~L}$ & 83.33 & SL & 87.5 & SL & 80.56 & SL & 81.60 & SL \\
\hline 8 & 75.00 & $\mathrm{~L}$ & 83.33 & SL & 87.5 & SL & 80.56 & SL & 81.60 & SL \\
\hline Rata2 & 82.29 & SL & 86.46 & SL & 84.38 & SL & 79.86 & SL & 83.25 & SL \\
\hline
\end{tabular}

Keterangan:

SL : : Sangat Layak

L : Layak

Berdasarkan Tabel 2, rata-rata hasil penilaian keberfungsian mobile learning aspek functionality sebesar 82,29 sehingga dikategorikan "Sangat Layak", aspek portability sebesar 86,46 sehingga dikategorikan "Sangat Layak, aspek usability sebesar 83,16 sehingga dikategorikan "Sangat Layak", dan aspek layout sebesar 79,86 sehingga dikategorikan "Sangat Layak".

Hasil total rata-rata penilaian keberfungsian mobile learning menurut para ahli sebesar 83,25 sehingga dikategorikan "Sangat Layak". Aspek keberfungsian terdiri dari functionality, portability, usability, dan layout. Berdasarkan uji validasi, mobile learning ini dapat berfungsi dengan baik, mudah dipasang di smartphone, penggunaanya mudah, dan pemilihan warna sudah sesuai. Hasil uji validasi juga terdapat beberapa indikator yang penilaiannya rendah. Penilaian terendah pada functionality terletak pada indikator performa aplikasi dengan nilai sebesar 67,50. Penilaian terendah pada portability terletak pada indikator adaptasi aplikasi dengan nilai sebesar 67,50. Penilaian terendah usability terletak pada indikator antusias siswa dengan nilai sebesar 67,50. Penilaian terendah pada layout terletak pada indikator pemilihan gambar dengan nilai sebesar 65 . Berdasarkan hasil uji validasi, mobile learning ini pada aspek keberfungsian masih terdapat kekurangan diantaranya: performa masih kurang karena aplikasi ini dapat dijalankan apabila ada koneksi internet, masih dirasa kurang menarik antusias siswa dikarenakan aplikasi ini masih kurang interaktif, dan pemilihan gambar dalam aplikasi ini masih dianggap kurang menarik sehingga perlu dilakukan perbaikan.

\subsection{Pembahasan}

Produk akhir dari penelitian pengembangan ini adalah tersebentuknya media pembelajaran berbasis mobile learning untuk siswa kelas X program keahlian Ketenagalistrikan pada mata pelajaran Pengukuran listrik. Nama aplikasi mobile learning ini adalah DPLdroid. Aplikasi ini dapat diunduh di playstore sehingga aplikasi ini hanya bisa digunakan di smartphone dengan sistem operasi android. Produk media pembelajaran ini sebelum divalidasi oleh dosen dan beberapa guru, media ini dilakukan uji black box testing. Hasil uji black box testing menunjukkan bahwa aplikasi ini dapat digunakan di berbagai smartphone dengan standar minimal sistem operasi android versi 5.0, ukuran layar smartphone 4", RAM 1 GB, dan terkoneksi dengan internet.

Penilaian validasi dosen dan guru dilakukan untuk mengetahui keberfungsian dan kelayakan mobile learning ini sebagai media pembelajaran. Hasil validasi berupa penilaian keberfungsian dan kelayakan media pembelajaran, serta saran dan rekomendasi untuk perbaikan media pembelajaran ini. Saran dan rekomendasi yang ada ditindaklanjuti untuk perbaikan media pembelajaran ini. Penilaian mobile learning ini dibagi menjadi dua yaitu penilaian kelayakan dan keberfungsian. Penilaian kelayakan terdiri dari aspek substansi materi dan desain pembelajaran, 
sedangkan penilaian keberfungsian terdiri dari aspek functionality, portability, usability, dan layout. Penjabaran masing-masing uji sebagai berikut.

\section{a. Uji Kelayakan}

Berdasarkan penilaian penilaian kelayakan mobile learning dari beberapa ahli diperoleh ratarata total sebesar 80,30 sehingga dikategorikan "Sangat Layak" dan penilaian total rata-rata respon siswa aspek kelayakan mobile learning sebesar 85,59 sehingga dikategorikan "Sangat Layak". Penilaian terendah pada kelayakan adalah kekinian materi dan penilaian terendah pada keberfungsian adalah keberfungsian aplikasi ini jika dijalankan dengan aplikasi lain. Hasil penilaian dari dosen dan guru beserta semua masukan, dijadikan sebagai masukan peneliti untuk memperbaiki mobile learning. Perbaikan mobile learning ini mencakup dua aspek yaitu aspek dari materi dan media. Perbaikan aspek materi diantaranya yaitu penambahan materi cara membaca alat ukur, cara membaca resistor, dan jembatan wheatstone. Selain itu, penambahan latihan soal tentang cara menganalisis rangkaian DC dan mengubah beberapa kalimat yang masih belum lugas. Perbaikan dilakukan untuk memenuhi prinsip media pembelajaran. Salah satu prinsip media pembelajaran adalah media yang dihasilkan harus memiliki tingkat relevansi yang tinggi dengan materi pembelajaran (Zabaleta, 2012: 7).

\section{b. Uji Keberfungsian}

Berdasarkan penilaian penilaian kelayakan mobile learning dari beberapa ahli diperoleh ratarata total penilaian keberfungsian sebesar 83,25 sehingga dikategorikan "Sangat Layak" dan hasil penilaian total rata-rata keberfungsian mobile learning oleh siswa sebesar 86,66 sehingga dikategorikan "Sangat Layak". Berdasarkan hasil tersebut, secara keseluruhan mobile learning ini dapat berfungsi secara baik. Perbaikan dari aspek media diantaranya adalah penambahan video cara membaca multimeter, perbaikan video analisis rangkaian, perbaikan beberapa gambar yang masih kurang menarik, dan menambah simulasi rangkaian sederhana. Perbaikan dilakukan agar aplikasi pembelajaran dapat meningkatkan minat siswa. Guo (2016: 86) menyebutkan mobile learning berhasil sebagai media pembelajaran jika minat siswa tinggi.

\section{KESIMPULAN}

Mobile learning materi Pengukuran Listrik untuk siswa SMK kelas $\mathrm{X}$ yang telah dikembangkan dapat berfungsi dengan baik dan layak untuk digunakan sebagai media pembelajaran. Berdasarkan analisis media ini sangat bermanfaat bagi sekolah, pendidik dan peserta didik karena dapat meningkatkan prestasi belajar peserta didik.

\section{REFERENSI}

1. Akhtar, A. \& Ali, R. (2008). Use of Media for Effective Instruction its Importance: Some Consideration. Journal of Elementary Education A Publication of Deptt. of Elementary Education IER, Vol. 18(1-2), 35-40. Retrieved from http://pu.edu.pk/images/journal/JEE/PDFFiles/JEE-18(1-2)\%20No_3.pdf.

2. Ally, M. (2009). Mobile learning Transforming the Delivery of Education and Training. Canada: AU Press, hal. 1.

3. Darmawan, D. (2012). Teknologi Pembelajaran. Bandung: Remaja Rosdakarya, hal. 15.

4. Djoub, B. \& Bari, M. (2016). An ISO 9126 Based Quality Model for the e-Learning Systems. International Journal of Information and Education Technology, Vol. 6, 370-375.

5. Hanafiah, N. \& Suhana, C. (2012). Konsep dan Strategi Pembelajaran. Bandung: Refika Aditama, hal. 59.

6. Haryoko, S. (2009). Efektivitas Pemanfaatan Media Audio-Visual sebagai Alternatif Optimalisasi Model Pembelajaran. Journal Edukasi @Elektro, Vol.5, 1-10. Retrieved from https://anzdoc.com/efektivitas-pemanfaatan-media-audio-visual-sebagai-alternati.html.

7. Heinich, R. Molenda, M., Russell, J.D., \& Smaldino, S.E.. (2002). Instructional Media and Technologies for Learning. Columbus: Merril Prentice, hal. 9.

8. Hulme, A.K dan Traxler, John. (2005). Mobile Learning, A Handbook for Educators and Trainers. USA: Routledge, hal. 1.

9. Husada. (2015). Mengapa Mobile Learning di Asia Tenggara Berpotensi Mengungguli Negara-Negara Lain di Dunia. Diaksees dari https://id.techinasia.com/potensi-mobilelearning-asia-tenggara pada tanggal 10 Maret 2015 pukul 21.30. 
10. Kearsley, G., Lynch, W., \& Wizer, D. (1995). The Effectiveness and Impact of Online Learning in Graduate Education. Educational Technology, Vol. 35, 37-42.

11. Kominfo. (2016). Kepemilikan Ponsel Menurut Umur. Diakses dari https://lokadata.beritagar.id/chart /preview/ kepemilikan- ponsel- menurut-rentang-umur-20161511347083 pada tanggal 18 Januari 2017 pukul 22.00.

12. Rath, K.A., \& Royer, J.M. (2002). The Nature and Effectiveness of Learning Disability Services for College Students. Educational Psychology, Vol. 14, 353-381.

13. Rodger, D. L. (2005). The Effect of Instructional Media on Learner Motivation. International Journal of Instructional Media, Vol. 32(4), 333-342. Retrieved from https://crystalbible.weebly.com/uploads/1/5/8/2/15829268/the_effectof_instructional_media.pd f

14. Tribun. (2017). Inilah Jumlah Pengguna Internet Pakai Smartphone dan Aplikasi Mobile Terpopuler di Indonesia. Diakses dari http://jogja.tribunnews.com/2017/04/01/inilah-jumlahpengguna-internet-pakai-smartphone-dan-aplikasi-mobile-terpopuler-di-indonesia pada tanggal 3 Mei 2017 pukul 21.00

15. Waryanto, N. H. (2008). Multimedia Interaktif dalam Pembelajaran. Jurnal tidak diterbitkan

16.Zabaleta, E. (2012). Media Based Learning: Lessons Learned and Open Ins. Lablearning Piration: EU, Hal. 7. 